\title{
JOMSTI
}

\section{Terminologi Gambus dalam Spektrum Musik di Indonesia}

\author{
Ricky Irawan \\ Program Study Musik, Institut Seni Indonesia Denpasr \\ Email: rickyirawan@isi-dps.ac.id
}

\begin{abstract}
This Article aims to review the expansion of the meaning of gambus in three categories. It is, firstly, the gambus as a musical instrument; secondly, gambus as a music performance format; and thirdly, stringed as a musical style. This categorization helps to understand the context in which the term gambus is used. Thus, the discussion about gambus can be understood more clearly. It was found that, initially, the term gambus is used to refer to a stringed musical instrument from the Middle East that came together with trading activities and the spread of Islam in Southeast Asia. But in its development, gambus is also used to refer to a format of musical performances such as orkes gambus, gambus Melayu, gambus tunggal and others. Later, gambus was used also to refer to musical styles associated with Islamic musical arts such as gambus dzikir, gambus sholawat, gambus qasidah. Seeing the various uses, it is difficult to interpret it only as the name of a musical instrument, but must also accommodate the expansion of its meaning at this time.
\end{abstract}

Keywords: gambus, terminology, musical instruments, music genres, categorization.

\begin{abstract}
Artikel ini bertujuan melihat perluasan makna gambus dalam tiga kategori. Pertama gambus sebagai alat musik. Kedua, gambus sebagai format pertunjukan musik. Ketiga, gambus sebagai gaya musik. Ketegorisasi ini membantu untuk memahami konteks dimana istilah gambus tersebut digunakan. Dengan demikian, pembicaraan mengenai gambus dapat difahami lebih dengan terang. Awalnya, istilah gambus digunakan untuk menyebut sebuah alat musik petik asal dari Timur-tengah yang datang bersamaan dengan aktifitas perdagangan dan penyebaran Islam di Asia Tenggara. Namun perkembangannya, gambus juga digunakan untuk menyebut suatu format pertunjukan musik seperti orkes gambus, orkes Melayu, gambus tunggal dan lain-lain. Belakangan, gambus digunakan juga untuk menyebut gaya musik yang dikaitkan dengan seni musik Islami seperti gambus dzikir, gambus sholawat, gambus qasidah. Melihat berbagai penggunaannya tersebut, sulit untuk artikannya hanya sebagai nama alat musik semata, melainkan harus pula mengakomodir perluasan maknanya saat ini.
\end{abstract}

Kata Kunci : gambus, termonilogi, instrumen musik, genre musik, kategorisasi.

\section{PENDAHULUAN}

Terminologi gambus dapat ditemukan dalam berbagai topik pembicaraan mengenai musik di Indonesia. Baik itu musik tradisi (lihat: Hastanto, 2005; Harahap, 2005; Hilarian, 2005; Kartomi,2012), maupun musik populer (lihat: Berg, 2005, 2007; 
Sutton, 2011, Capwell, 2011; Barendregt \& Zanten,2015). Baik musik religius (Sholikhah,2008 ; Rasmussen, 2010) maupun musik sekular (Berg, 2005; Irawan,2008). Meski demikian, hal ini tidak membuat makna dan pengertian istilah ini terang sekaligus mudah dipahami. Sebaliknya, istilah gambus yang mencakup banyak berbagai dimensi di dalam musik itu seringkali membingungkan dan membawa kerumitan tersendiri. Hal ini sebagaimana diungkapkan oleh Berg (2005:3),

Orkes gambus is also sometimes simply called gambus, causing it to be confused with regional gambus. The term gambus, means many things in Indonesia. It can refer to a plucked instrument, the traditional Hadramiderrived alat, the modern 'ud instrument, a form of regional singing and dance, or Arab-Indonesian orkes gambus ensamble music and dance.

Tampaknya penggunaan terminologi gambus yang beragam itu membuat maknanya seringkali tumpang tindih dan mengambang. Gambus mengacu pada nama sebuah alat musik petik modern asal Arab berbentuk separuh bulatan telur atau ditempat asalnya dikenal dengan nama 'oud. ${ }^{1}$ Namun ia juga digunakan untuk menyebut alat musik petik ukuran kecil dengan membran kulit yang diduga asal Timur-tengah. Penelusuran lebih lanjut, kita mendapati nama-nama lokal yang beragam untuk kedua alat musik tersebut. Misalnya saja gambus semangka, gambus zapin, gambus Palembang (Harahap, 2005:103-104), gambus albar, gambus balak, gambus buha, gambus lunik (Irawan,2008:73; Hastanto,2005:), gambus Hadhramaut, gambus Melayu, gambus seludang, gambus biawak, gambus Hijaz (Hilarian, 2005:66-67). Belum lagi terdapat alat musik petik lain di Nusantara yang juga dianggap sebagai gambus, seperti gambus bagan (Lampung) (Irawan, 200874), hasapi (Toba), kulcapi (Karo), Tingkilan, (Kalimantan) dan Jungga (Sumbawa) (lihat: Siagian, 2006:14; Hilarian, 2005:66), gambusi / kacapi (Pulukadang, 2007:80).

Selain digunakan sebagai nama alat musik, terminologi gambus juga digunakan untuk menyebut suatu kumpulan alat musik (ensambel), dimana gambus dimainkan bersama alat musik lainnya, seperti darabukha, tamtam, marawis, keyboard, akordion, biola, gitar, dan lainnya. Ensambel semacam ini sering disebut

\footnotetext{
${ }^{1}$ Penulisan Arab untuk alat ini adalah عود ('Oud) masyarakat Indonesia mengejanya menjadi 'Ud. Kata Oud sendiri menurut Sadie (1984:551) memiliki kesamaan arti dengan "Wood" dalam bahasa latin yang kemudian membentuk kata "Lute" untuk menyebut alat musik yang sama dalam budaya musik Eropa.
} 
orkes gambus. Namun, dengan komposisi alat yang kurang lebih sama, ensambel semacam ini dapat juga disebut sebagai orkes zapin (Berg, 2007:3). Deferensiasi penggunaan kedua istilah itu sekilas tampaknya dapat dilihat melalui konteks pertunjukannya. Orkes gambus dipertunjukan dalam konteks keislaman (Berg,2007:7) ; sementara orkes zapin berkaitan erat tari zapin atau gaya musik tari zapin yang populer dalam kebudayaan Melayu. Namun lagi-lagi, kita akan dibingungkan dengan istilah lain, yakni orkes Melayu yang acuannya tidak relatif tidak berbeda dengan orkes gambus dan orkes zapin.

Beberapan tahun belakangan media masa maupun media sosial, diramaikan oleh grup musik Gambus Sabyan. Kelompok musik ini dikenal sejak tahun 2015 dan mampu menarik perhatian publik musik Indonesia melalui hits seperti Deen Asslam, Ya Habibal Qolbi, , Ya Maulana, dan Ya Asyiqol Musthofa (As'ad, 2018). Menarik untuk dicermati, Gambus Sabyan meski menggunakan nama gambus, musiknya justru tidak diwarnai dengan alat musik gambus atau format orkes gambus. Untuk itu, kita dapat bertanya, dimana relevansi istilah gambus yang telah disinggung di atas dalam konteks semacam ini? Kebingungan-kebingungan ini mungkin bukan akhir. Popularitas kelompok musik Sabyan Gambus kemudian mendorong munculnya musik-musik dengan sebutan seperti gambus qasidah dan gambus sholawat. Lalu bagaimana kemudian istilah gambus sebaiknya dipahami?

Melihat diversitas penggunaan istilah gambus sebagaimana dijelaskan di atas, cukup menghadirkan kebingungan untuk memahaminya satu sama lain. Tidak bermaksud mengkoreksi penggunaan dan pemaknaanya di tengah-tengah masyarakat, tulisan ini mencoba menyelami bagaimana terminologi gambus digunakan, kaitannya satu sama lain, dan sekaligus berupaya mengelompokannya dalam suatu kategorisasi musik dengan tujuan mengurai kompleksitas dan keberagaman penggunaan istilah gambus itu sendiri di masyarakat.

METODE

Untuk menjawab persoalan yang dikemukakan dalam artikel ini, penulis menggunakan metode studi pustaka yang berkaitan dengan penggunaan istilah gambus di Indonesia. Literatur ini meliputi kajian baik dalam ranah etnomusikologi ataupun musikologi. Baik itu penelitian yang menggunakan perspektif sejarah, sosiologis, maupun antropologis. 
Study pustaka (literature study) adalah upaya penelusuran dan penelitian kepustakaan dengan memeriksa berbagai buku, jurnal, dan terbitan-terbitan lain yang berkaitan dengan isu atau topik penelitian dengan tujuan menghasilkan satu tulisan berkenaan dengan satu topik atau isyu tertentu.yan dibahas. Setidaknya terdapat dua tujuan penggunaan metode ini. Menurut Berg dan Lune (dalam Marzali, 2016:28), setidaknya ada dua tujuan utama dari kajian literatur. Pertama, studi pustaka bertujuan menghasilkan makalah guna memperkenalkan kajian-kajian baru dalam topik tertentu. Kedua, kajian literatur bertujuan memperkaya wawasan akan suatu topik dan isu guna membantu dalam memformulasikan masalah, menentukan teori-teori, metode yang tepat untuk digunakan dalam penelitian kita. Dengan mempelajari kajian-kajian yang dihasilkan peneliti lain, kita dapat menentukan apakah akan meniru, mengulangi, atau mengeritik satu kajian terdahulu.

\section{PEBAHASAN}

\section{Asal Mula Terminologi Gambus}

Sebelum mendiskusikan berbagai penggunaan terminologi gambus dan relevansinya, akan berguna terlebih dahulu membicarakan asal-usul istilah ini. Penelusuran asal-usul istilah gambus akan membantu kita memahami konteks awal penggunannya, serta perluasan dari makna awalnya.

Sejarahwan musik umumnya mengatakan bahwa gambus adalah kosakata yang diserap dari luar budaya musik Nusantara untuk menyebut sebuah alat asal Timur-tengah. Keberadaan alat musik ini dikaitkan dengan migrasi orang-orang Islam Arab yang datang ke Asia Tenggara dalam perdagangan maupun penyebaran ajaran Islam. Namun demikian, dari mana tepatnya asal kata gambus itu sendiri masih terbuka untuk diperdebatkan.

Catatan paling awal mengenai gambus tampaknya berasal dari Curt Sachs pada bukunya yang berjudul The History of Musical Instruments. Sachs dalam buku tersebut menjelaskan (1940:251),

Islamic migration and conquests carried this lute eastward from Persia as Far as Celebes, and southwards to Madagascar. In all these countries it has been called by name probably of Turkish origin, and variously spelled by as gambus, kabosa or qopuz.

Catatan selanjutnya kita dapati dalam buku Jaap Kunst yang berjudul Music in Java : Its History, Its Theory, and Its Technique. Kunst (1949:373) menjelaskan, 
The name derives from the Arabic name for this alat $t$, i.e. qopuz (via the East-African form, gabbus). The alat $t$ has the form of a long-drawn, pearshaped lute with a wooden sound-box which is only very slightly arched.

Terdapat beberapa hal yang menjadi perhatian dalam pendapat Sachs tersebut, 1) Migrasi Islam membawa alat musik ini ke Persia (Iran saat ini) menyebar ke arah Timur hingga Celebes (Sulawesi) dan ke Selatan hingga Madagaskar. 2) Di berbagai wilayah persebarannya, alat musik ini menggunakan istilah yang berasal dari orang-orang Turki. 3) Alat musik ini memiliki berbagai istilah lokalnya masing-masing, sehingga kemudian dikenal istilah-istilah seperti, yakni gambus, kobosa, dan qapuz. 4) Kunst menduga bahwa istilah gambus ini juga berkiatan dengan istilah gabbus dalam budaya musik Afrika Timur.

Nama-nama yang disebut oleh Sachs dan Kunst memiliki kemiripan satu sama lain. Namun istilah gabbus sebagaimana dikemukakan oleh Kunst agaknya relatif dekat dengan penyebutan gambus. Menarik pula bahwa alat ini di tempat asalnya di Timur-tengah dan Afika memiliki kemiripan dengan istilah gambus, yakni qanbus, gabusi (Oman \& Zanzibar), gabusi/ gambusi (Comoro) (Irwansyah,2005:103).

\section{Gambus sebagai Alat Musik}

Melalui penelusuran istilah gambus di atas, jelas bagi kita bahwa istilah ini pertama-tama digunakan untuk menyebut sebuah alat musik. Pertanyaan selanjutnya adalah, alat musik seperti apa yang dimaksud dengan qopuz, gambus, gabbus, dan kaboza? Apakah kesemuannya adalah alat musik yang sama? Baik Sachs maupun Kunst tidak menyertakan visualisasi alat qopuz, gambus, gabbus, dan kaboza. Namun keduanya memberikan gambaran tentang alat yang dimaksud. Kutipan Kunst sebelumnya menjelaskan, alat ini memiliki ciri-ciri "has the form of a long-drawn, pear-shaped lute with a wooden sound-box which is only very slightly arched". Sementara Sachs (1940:251).menggambarkan,

a single piece of wood with no distric neck and tapering towards the pegbox, are found first in Iran.. its pegbox was bent beckwards in a sickle shape and contained leteral pegs; the stingholder was not frontal but on the lower end of body, and a skin served as the soundboard.

Ciri-ciri yang dijelaskan baik Kunst maupun Sachs mengarah pada alat gambus yang oleh banyak masyarakat Indonesia disebut sebagai gambus Melayu. Istilah Melayu sendiri digunakan untuk membedakan alat lain yang disebut sebagai 
gambus Arab (oud/ ud) dengan ukuran yang lebih besar dan konstruksi organologis yang juga berbeda. Berikut dibahas dua alat gambus yang dimaksud.

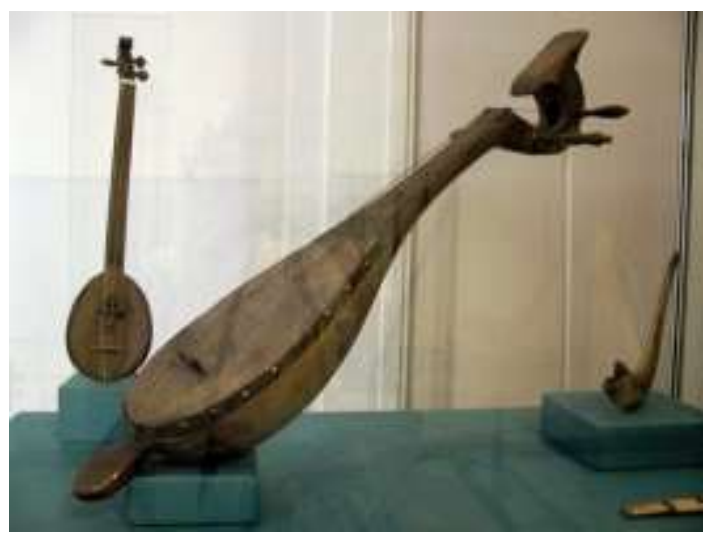

Gambar 1: qanbus koleksi Kunsthistorisches Museum, Vienna

Sumber:

https://commons.wikimedia.org/wiki/File:Qan buz.JPG

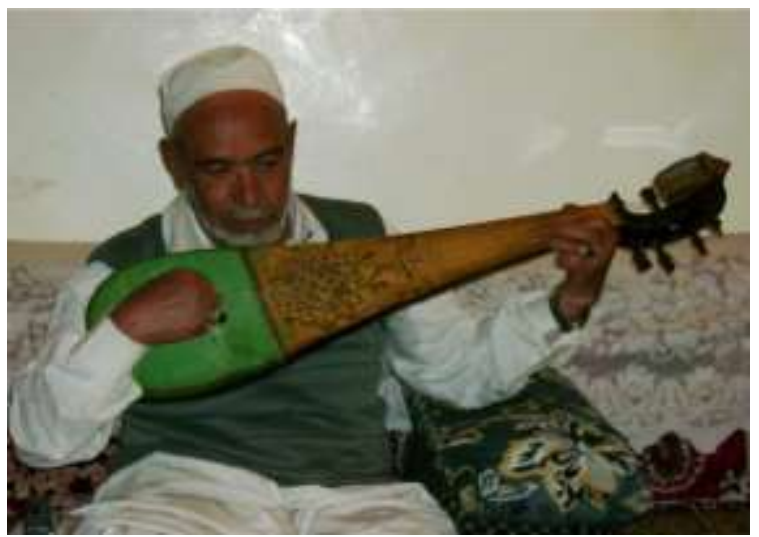

Gambar 3: qanbus (Yaman)

Sumber: https://al-bab.com/albaborig/albab/bys/articles/mokrani11.htm

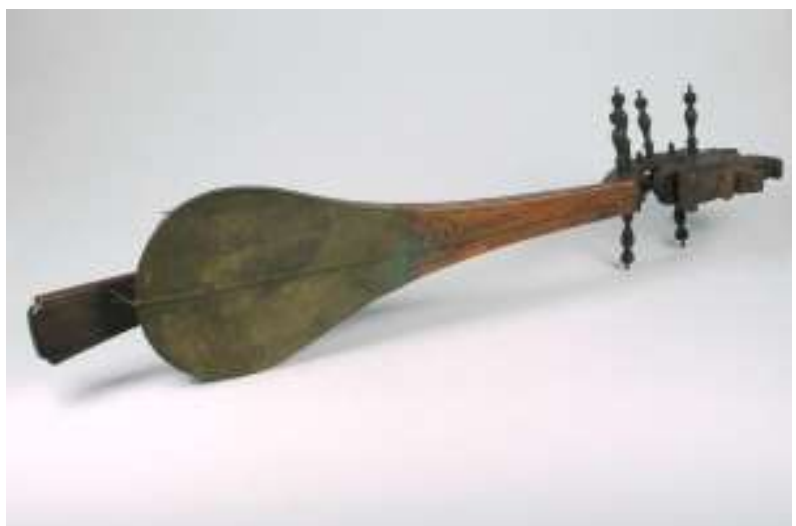

Gambar 2: qanbus koleksi Tropen Museum.

Sumber:

https://commons.wikimedia.org/wiki/File: COLLECTIE TROPENMUSEUM Lang halsluit met vier snaren TMnr $\mathrm{H}$ 1690.jpg

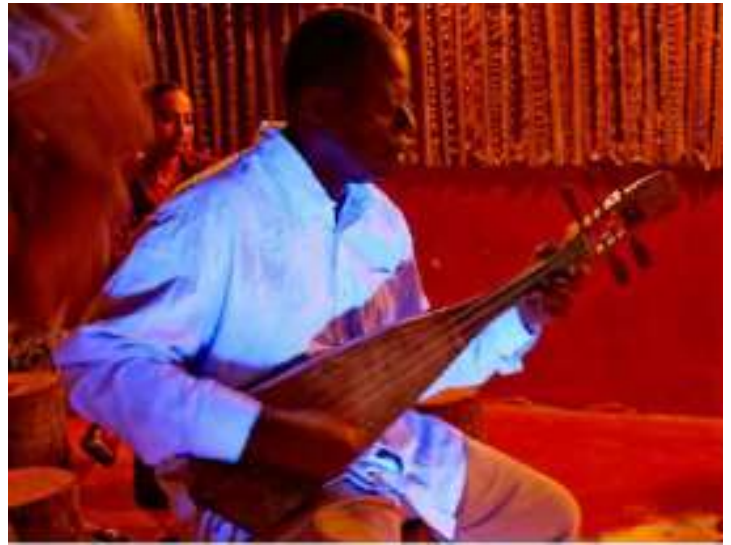

Gambar 4: gabusi (Swahili/ Comoros) Sumber:

http://inthegapbetween.free.fr/pierre/

1. Gambus Melayu

Secara ukuran, gambus Melayu memiliki ukuran yang lebih kecil dibandingkan dengan gambus Arab yang akan dibahas belakangan. Gambus Melayu ini dibuat dengan kayu utuh, tabung resonator bagian belakangnya tidak terpisah dengan bagian neck, sementara bagian muka resonatornya ditutup dengan kulit (kambing/ sapi). Sementara bagian kepala (pegbox) berupa hiasan dekotarif yang beragam tiap-tiap daerah. Dawai gambus Melayu terdiri dari 4 dengan tunning yang berjarak 
perfect $4^{\text {th }}$. Tunning gambus Melayu ini juga bervariatif. Tunning gambus Melayu di Indonesia dan Malaysia umumnya adalah A-D-G-C. Dibeberapa tempat di Riau Kepulauan tunning-nya (dari rendah ketinggi) adalah G-D-G-C (Hilarian, 2006:56).

Gambus Melayu tampaknya adalah jenis gambus yang populasinya paling banyak tersebar di Nusantara. Persebarannya diberbagai wilayah membuat ia memiliki banyak nama lokal. antara lain, gambus lunik, gambus buha, gambus lappung (Lampung) (Irawan,2008; Hastanto; Kartomi), gambusi / kacapi (Pulukadang, 2007:80). Sementara itu di Malaysia dan Brunei Darusalam gambus semacam ini disebut gambus seludang, gambus biawak, gambus Hijaz (Hilarian, 2005:66-67). Juga perlu disebutkan di sini gambus Melayu juga dikenal dengan nama gambus zapin. Hal ini sebabkan alat musik petik ini digunakan sebagai pengiring tarian zapin.

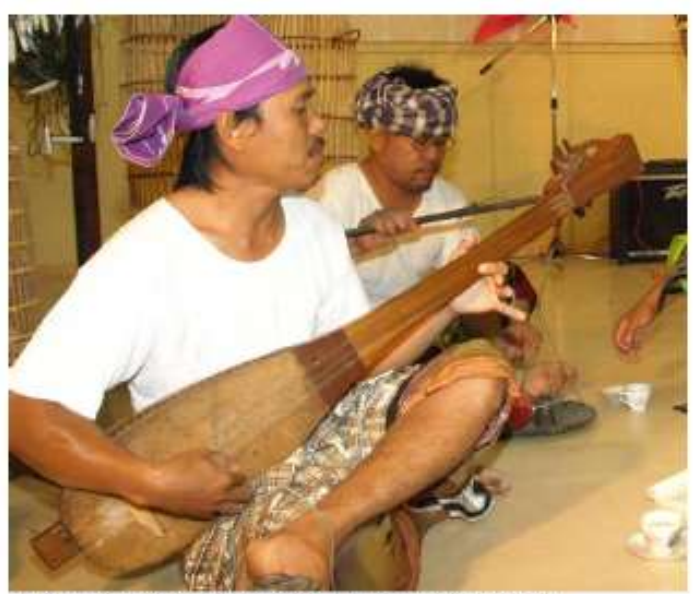

Thin shaped Gambus Biawak lute (Beaufort, Sabah).

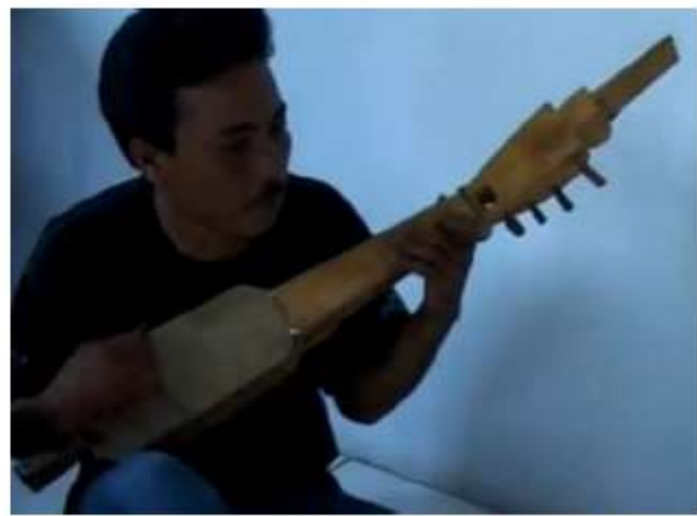

That typical sulawenese design borrowed from the local Kecapi

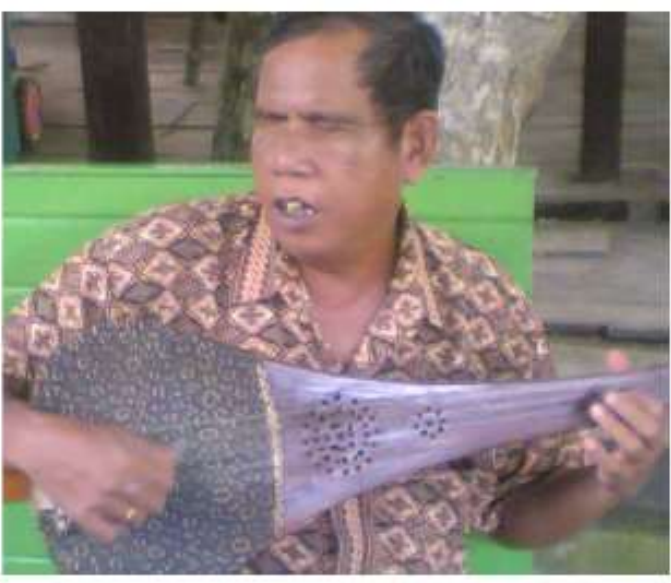

Thin shaped Panting lute (Teggenrung, eastern Kalimantan). Outlet are drilled in the fingerboard. Snake skin made resonator.

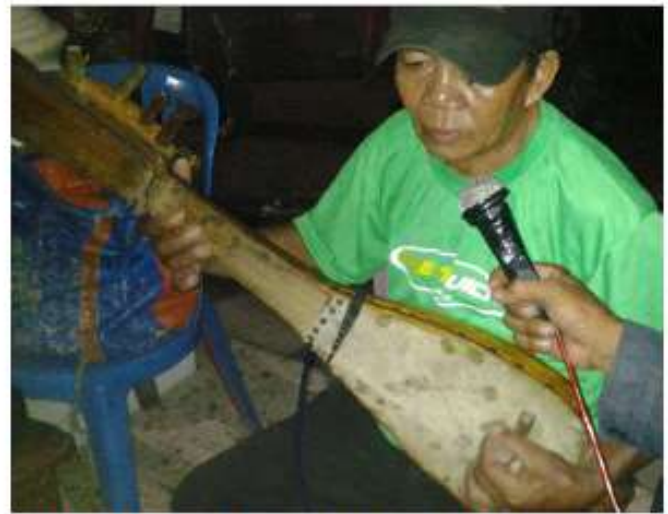

Gambus lute of the folklorical troupe Kobi Tallua (Makasar, SW Sulawesi).

Gambar 5: berbagai varian gambus Melayu

(Sumber:http://inthegapbetween.free.fr/) 
Selain memiliki nama lokal yang berbeda-beda, gambus Melayu ini juga pada dasarnya memiliki sejumlah perbedaan satu sama lainnya. Perbedaan itu dapat berupa, jumlah dawai, ornamen bagian kepala, ukuran tabung resonator, maupun panjang bagian neck. Sering kali perbedaan-perbedaan dapat menunjukan dari daerah mana gambus tersebut berasal. Seringkali yang menjadi identitas ini ada pada ornamentik bagian kepala (pegbox) sebagaimana ditujukan dalam gambar berikut.
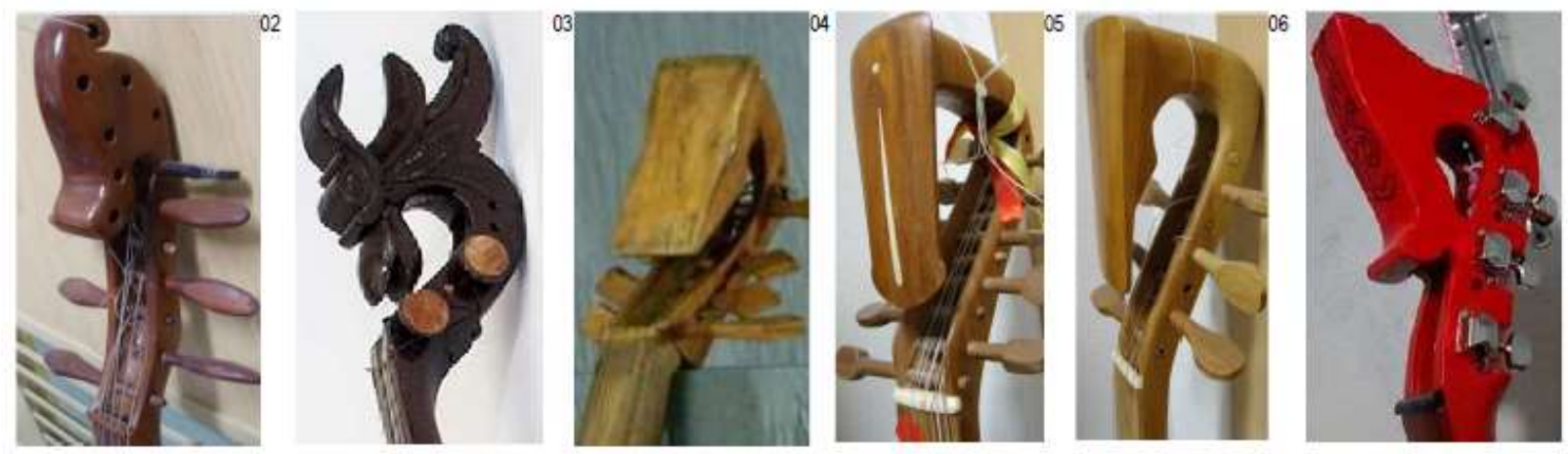

Variations on the deco pattern of the naga. ITEM n 02 (Bengkalis) $n^{\circ} 03$ (Lampung/Lunik), $n^{\circ} 01,04$ (Medan), $n^{\circ} 05$ (Penyangat, Riau), $n^{\circ} 06$ (Bintan, Riau Isl)
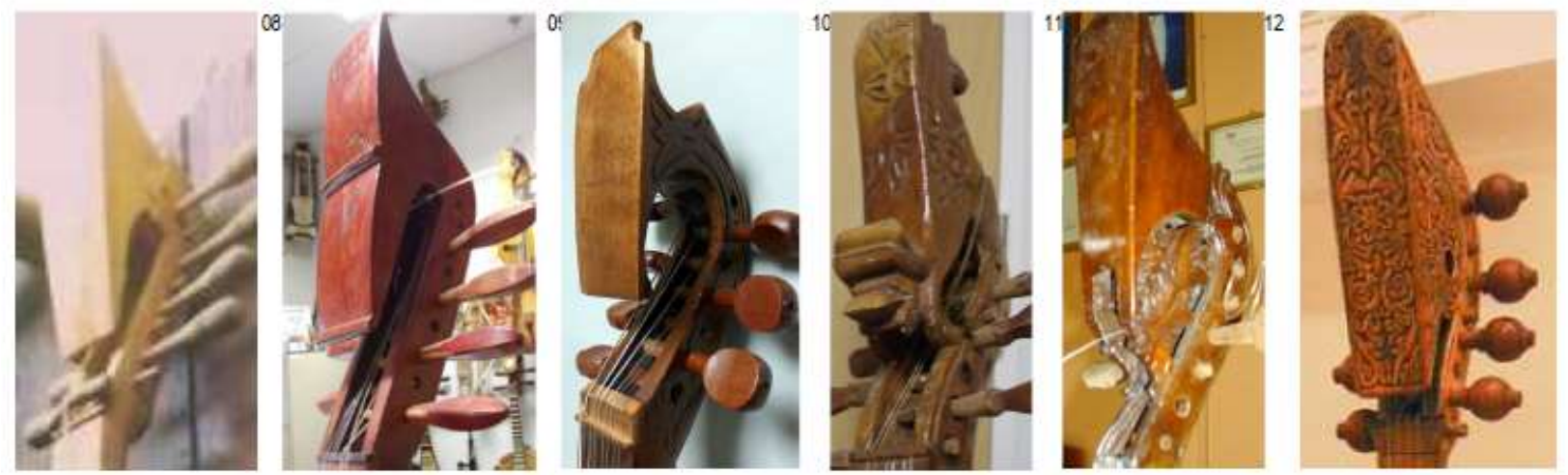

Variations on the deco pattern of the naga, ITEM $n^{\circ} 07$ (Tajung Batu, Riau Isl), $n^{\circ} 09$ (Johore Baru, Malaysia), $n^{\circ} 10$ (Sumatra) $n^{\circ} 08$ \& 11 by BIN OSMAN (Batu Pahat, Malaysia), $n^{\circ} 12$ (Malaysia)

Gambar 6: berbagai varian gambus Melayu

(Sumber:http://inthegapbetween.free.fr/)

\section{Gambus Arab (Al-Oud/ 'Ud)}

Gambus Arab berbentuk separuh bulatan telur, yang mana seluruh bagian tabung resonatornya berupa kayu. Bagian leher (neck) yang berukuran pendek, bagian depan yang datar (Soundboard), terdapat satu atau lebih lubang suara (soundhole). Sementara itu pada bagian belakangnya yang cembung, dibentuk oleh dua belas (umumnya) kayu pipih (ribs) yang disambungkan. Terdapat beberapa variasi jumlah dawai pada gambus Arab ini ada yang berjumlah 9 dawai dan 11 
dawai yang terbuat dari nilon sebagaimana gitar klasik. Bunyi dawai gambus Arab juga bervariasi. Sebagaimana gambus Melayu, tunning yang umum juga berjarak perfect $5^{\text {th }}$ (dari rendah ketinggi) yaitu : C-G-D-A-E-B. Gambus Arab ini juga memiliki berbagai nama lokal, seperti gambus Hadhramaut, gambus Palembang (Hilarian,2005:66; Harahap,2005:103-104), gambus albar, gambus balak (Irawan,2008:73). Akhir-akhir ini terdapat kecenderungan dari para pemusik gambus, untuk menyebut alat musik ini sebagaimana nama aslinya, yakni oud. Agaknya hal ini ditujukan untuk membedakannya dengan gambus Melayu. Berikut visual gambus Arab yang dimaksud.
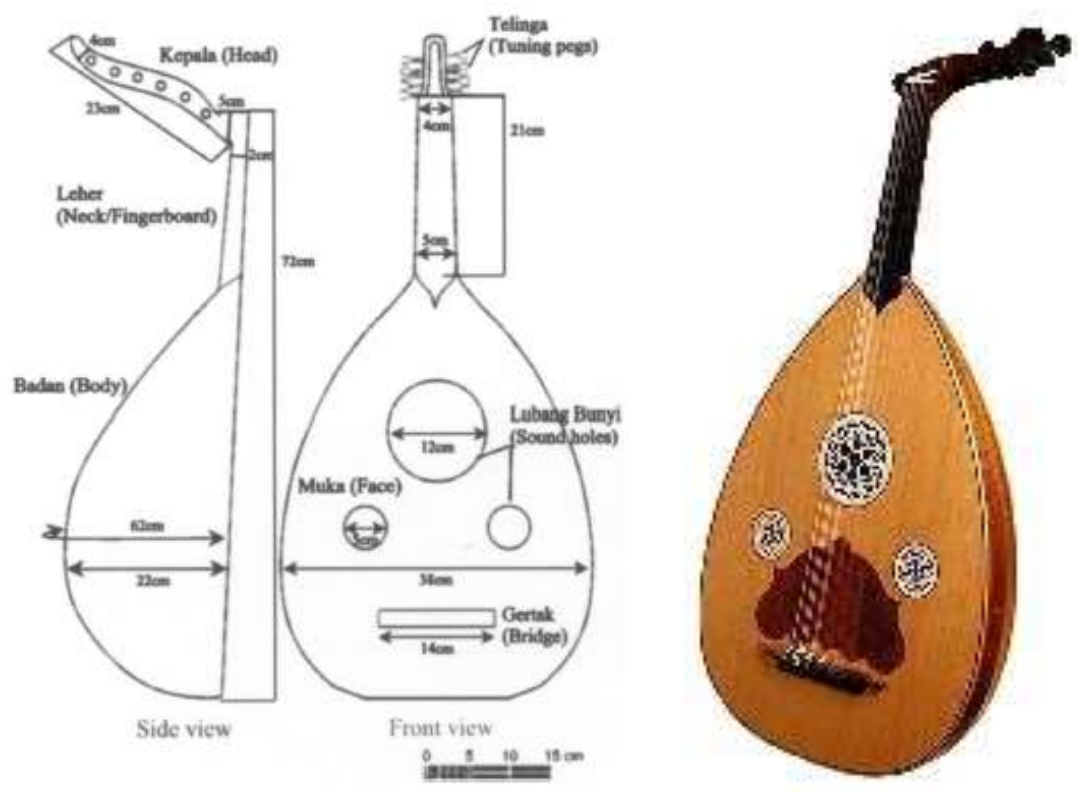

Gambar 3: jenis-jenis gambus Arab (oud) (sumber: Hilarian:2005:69)

\section{Gambus sebagai Sususan Instrumen}

Dapat dikatakan terminologi gambus mengalami apa yang disebut sebagai peluasan makna, dari sebatas nama suatu alat musik kemudian menjadi penamaan suatu format musik. Sebagaimana diketahui, dalam konteks pertunjukannya, gambus dapat dimainkan dalam berbagai bentuk sajian. Apakah itu berbentuk solo untuk mengiringi nyanyian. Ataupun bentuk yang lebih besar dengan kombinasi alat -alat musik lainnya (ensambel). Terdapat beberapa nama untuk menyebut formatformat pertunjukan semacam ini, antara lain, gambus tunggal, pantingan, orkes gambus, orkes Melayu, gambus zapin. Nama-nama orkes gambus, gambus Melayu, 
gambus zapin, seringkali sulit dibedakan relevansinya. Namun sebagian lagi dapat dibedakan menurut konteks pertunjukan, jenis genre yang dimainkan, serta komposisi alat-alat musik yang menyertai di dalam ensambel. Untuk memahaminya relevansi penamaan tersebut, berikut akan dibahas format pertunjukan tersebut.

1. Gambus Tunggal

Format gambus ini mungkin yang paling banyak ditemukan dalam konteks musik tradisi di Indonesia dengan nama beragam seperti, peting gambus tunggal (Lampung) (Irawan,2008), panting (Samarinda), gambus tunggal (Lombok), tingkilan (Kutai). Namun perlu pula diperhatikan, istilah pating dan tingkilan juga mengalami perluasan makna sebagaimana istilah gambus. la dapat digunakan sebagai nama alat musik sekaligus juga format pertunjukan secara tunggal maupun secara ensambel.

. Format tunggal semacam ini digunakan sebagai pengiring nyanyian berbahasa lokal. Bentuk lirik dari nyanyian ini dapat berupa syair ataupun pantun dengan tema-tema yang beragam seperti cinta, nasehat, ratapan kesedihan, keindahan alam, dan lain-lainnya.

2. Orkes Gambus/ Orkes Melayu

Istilah orkes gambus ini tampaknya yang paling membingungkan dan bersifat tumpang tindih - meskipun secara literal orkes gambus berarti alat gambus yang dimainkan dalam bentuk orkes bersama alat-alat musik lainnya seperti darabukha, tamtam, marawi, biola, serunai (nay), gitar, bass, akordeon juga seringkali digunakan. darabukha, tamtam, marawis dan lain-lain. Sementara itu, gambus yang digunakan dalam format ini dapat berupa gambus Arab maupun gambus Melayu.

Orkes gambus ini dipertunjukan dalam berbagai konteks religus dan sekular. Konteks religius membuat orkes gambus seringkali diidentifiaksikan dengan musik Islam, atau sekurang-kurangnya bernafaskan Islam. Alasan ini mungkin disebabkan konteks pertunjukannya ada acara-acara keislaman, misalnya dalam acara tausiah, menyambut ramadhan,idul fitri (halal bi hala), kegiatan masjid, dan lain-lain. Pertunjukan jenis ini umumnya menggunakan lirik berbahasa Arab yang berupa sholawat, qasidah (Puisi religius), dzikir, dan kisah-kisah Rasullulah yang diambil dari kitab Barzanji. Meski demikian, idintifikasi orkes gambus sebagai musik Islami juga bersifat problematis. Berg (2011:208) menujukan stereotype orkes gambus sebagai musik Islam ini terkadang didasarkan pada alasan-alasan yang justru 
ambigu. Selain juga tidak semua komunitas Islam setuju bahwa orkes gambus sebagai musik Islam. Penggunaan struktur musik Arab (sistem maqom,alat musik Arab, irama padang pasir), dan bahasa Arab, yang menjadi tolak ukur penyebutan orkes gambus sebagai musik Islam tentu saja bersifat inkonsisten. Sebab struktur musik musik Arab dan bahasa Arab yang dimainakan tidak selalu berkaitan dengan religiusitas Islam.

Di luar konteks keislaman sebagaimana dijelaskan di atas, orkes gambus juga dipertunjukan dalam konteks hiburan (popular/ sekular). Format musik dalam konteks ini agaknya disebut sebagai orkes Melayu. Menurut Weintraub (2016:59). Istilah orkes Melayu sendiri muncul di Indonesia tahun 1930an melalui radio-radio. "Orkest Malajoe Sinar Medan" pimpinan Abdul Halim adalah salahsatu yang paling awal dengan membawakan musik-musik Melayu dengan harmonisasi alat musik barat. Kelompok musik ini mempertahankan karakteristik musik Melayu yang struktur liriknya yang berupa pantun, standar pola-pola melodi, gaya ornamentasi, dan penambahan kata-kata seperti "aduhai sayang", "tuan" disela-sela liriknya.

Meski demikian, dikotomi orkes gambus dan orkes Melayu berdasarkan konteks pertunjukan dan repertoar yang dimainkan juga problematis Sebab kelompok musik orkes gambus tidak hanya berada dalam satu sisi dikotomi semacam itu, melainkan bergerak di kedua sisinya. Hal ini seperti Orkes Melayu Sinar Kemala, pimpinan A.Kadir, dalam albumnya mencakup tema-tema keislaman seperti sholawat, cinta, nasehat bijak, hingga nasionalisme.

\section{Gambus sebagai Genre/ Gaya Musik}

Selain digunakan untuk menyebut alat musik dan susuan alat musik sebagaimana dijelaskan sebelumnya, istilah gambus digunakan untuk menyebut suatu gaya musik ${ }^{2}$ dengan berbagai karakteristik yang disematkan padanya. Meski demikian, karakteristik ini dapat bersifat eksplisit maupun implisit. Implisit artinya, gaya masik ini masih dapat dikaitkan dengan gambus, baik sebagai alat musik gambus maupun susunan alat musik gambus. Sementara yang dimaksud implisit,

\footnotetext{
2 Gaya musik secara luas dapat dimaknai berupa karakteristik, ciri-ciri, ataupun identitas yang melekat dan yang membedakan suatu musik dengan musik yang lain. Seringkali yang menjadi perhatian dalam membedakan satu musik dengan lain ada pada elemen-elemen musik itu sendiri, seperti melodi, ritme (irama), harmoni, struktur musik, warna suara, dan lain-lainnya.
} 
keterkaitan itu tidak terlihat selain nuansa atau struktur musik yang dimainakan gambus secara solo maupun orkes.

Pembicaraan mengenai gambus dalam konteks gaya musik di sini menekankan pada musik-musik yang dimainkan oleh gambus itu sendiri, baik dalam format tunggal maupun orkes. Perbedaan antara permainan gambus tunggal dengan orkes gambus seringkali lebih berupa pengayaan kompleksitas elemen-elemen musiknya. Dalam artian, musik yang sama dapat dimainkan secara orkes atau tunggal. Penambahan dan pengurangan ini tentu saja berdampak pada elemenelemen seperti harmoni yang dihasilkan dari perpaduan berbagai alat musik, irama yang diperkuat oleh alat musik perkusif, serta kekayaan warna suara yang didapat dari alat-alat musik melodis lainnya.

Akan lebih mudah pembicaraan ini dimulai dengan pertanyaaan, musik apa yang dimainkan oleh alat musik gambus (baik secara tunggal dan orkes)? Jawaban dari pertanyaan ini tentu saja tidak tunggal, karena musik yang dimainkan oleh gambus pada kenyataannya memang beragam. Untuk itu akan dipaparkan beberapa genre musik gambus yang dapat dilacak untuk menunjukan keberagaman itu sendiri.

\section{Genre Lagu Melayu}

Salah satu genre yang paling dikenal dan banyak dimainkan gambus secara tunggal maupun orkses, adalah genre lagu Melayu. Sebagaimana namanya, lagu Melayu menyebar diseluruh alam Melayu, baik itu di Indonesia maupun Malaysia. Menurut Weintraub (2010:61) lagu Melayu telah eksis sejak akhir abad ke 19 dan berkembang dari waktu ke waktu. Lagu Melayu juga genre yang beragam berdasarkan wilayahnya, seperti lagu Melayu Deli (Medan), orkes Melayu Jakarta, dan orkes Melayu Surabaya. Namun diyakini banyak orang, Deli merupakan asal di mana lagu-lagu melayu asli berkembang. Lagu-lagu Melayu pada dasarnya dibuat berdasarkan lirik dan formula yang telah ada sebelumnya yang kemudian dikembangkan baik secara spontan maupun terrencana untuk tujuan-tujuan tertentu. Liriknya berupa pantun dan skema rima berbentuk A-B-A-B (Weintraub,2010:62).

Selain dinyanyikan secara tunggal maupun dengan orkes gambus, lagu Melayu biasanya dinyanyikan secara bersahutan dan tidak terpisah dari aktiftas menari ketika dinyanyikan. Selain itu lagu Melayu sedkitnya terbagi menjadi 3 pola 
lagu yang dibedakan berdasarkan iramanya, yakni : senandung dengan ciri lambat dan metrum quadruple ; mak inang (tempo moderat, quadruple meter); dan lagu dua atau joget (cepat triple meter atau duple meter with triple subdivisions).

\section{Gambus Zapin}

Zapin sebagaimana diketahui adalah nama sebuah tarian yang populer dalam kebudayaan Melayu sekaligus dalam komunitas Islam. Tarian ini digunakan dalam festival maupun perayaan-perayaan yang berkaitan dengan keagamaan maupun hiburan. Terdapat berbagai penyebutan dimasing-masing daerahnya, misalnya jepen, zhafana, gambus, qanbous, marwas, dana, bedana dan lain-lainnya (Yampolski,1996:7). Perbedaan nama ini juga mungkin berbanding lurus dengan perbedaan dalam musik dan gerakan tarinya.

Tarian ini diiringi oleh orkes gambus dengan instrumentasi yang umumnya terdiri dari gambus Melayu, marwas (marawis), biola, flute, keyboard, gitar elektrik, bass elektrik. Pemain gambus dalam orkes gambus zapin ini biasanya merangkap sebagai penyanyi, sebuah kebiasaan yang kita temui dalam permainan gambus tunggal maupun orkes.

Repertoar yang dimainkan sebagai pengiring tarian ini disebut sebagai 'lagu gambus', kumpulan lagu yang dapat digunakan sebagai pengiring tari zapin. Namun demikian lagu-lagu gambus sebagai pengiring tari zapin ini, sebagaimana lagu Melayu, agaknya berupa suatu bentuk musik yang telah eksis sebelumnya dengan mengubah liriknya. Pengubahan lirik ini memungkinkan lagu gambus untuk tari zapin digunakan di luar perannya sebagai pengiring tari. Tampaknya ini yang menyebabkan istilah gambus zapin, orkes zapin, lagu zapin mendapatkan konteksnya dalam pertunjukan musik yang otonom.

3. Gambus Sholawat/ qasidah / dzikir

Istilah sholawat (shalawat/ shalawatan) berasal dari bahasa Arab yang bermakna doa atau puji-pujian kepada Nabi Muhammad SAW yang berupa teks atau puisi berbahasa Arab. Istilah sholawat sendiri seringkali dibingungkan dengan istlah-istilah lain yang mengacu pada teks-teks sastra dan genre musik lain seperti barjanzi dan burda atau qasidah burda yang masing-masingnya memang miliki kemiripan dengan sholawat. Untuk itu akan lebih mudah dipahami apa bila istilah sholawat ini dianggap sebagai payung besar yang menyatukan berbagai genre teks pujian berbahasa 
Arab. Maka teks seperti marhaban, rawi, dan lagu-lagu naratif lain juga dapat dikelompokan sebagai bagian dari sholawat.

Teks sholawat melahirkan banyak gaya musik yang terkait dengan format pertunjukannya. Nyanyian sholawat badar dengan iringan orkes gambus misalnya mendapat sebutan gambus sholawat. Jika sholawat dimainkan dengan iringan alat musik rebana maka disebut dengan sholawat rebana/ terbangan, sholawat qasidah, atau qasidah modern. Agaknya penyebutan semacam ini yang melahirkan istilahistilah populer saat ini seperti gambus dzikir dan gambus qasidah.

Istilah gambus sholawat, gambus dzikir, maupun gambus qasidah sebagaimana dikenal saat ini memiliki keterkaitan langsung sekaligus tidak langsung pada pengertian gambus sebagai alat musik ataupun sebagai format pertunjukan musik. Penggunaan istilah gambus qasidah mengacu pada orkes gambus yang menyanyikan genre musik qasidah. Fenomen semacam ini dapat dilihat pada karyakarya qasidah gambus Mas'ud Sidik berbahasa Indonesia namun dengan iringan musik yang kental dengan gramatikal musik Arab. Sementara keterkaitan tidak langsung, dapat ditemukan pada fenomen qasidah gambus modern yang tampaknya tidak lagu mengadopsi gramatikal musik Arab secara penuh (baik itu alat musik maupun sistem maqam-nya). Sebagai gantinya justru gramatiikal musik Barat mendapatkan peran yang lebih penting. Contoh ini dapat ditemukan dalam berbagai fenomen musik religi yang berkembang belakangan seperti Gambus Sabyan. Liriklirik yang dinyanyikan, tema-tema yang dibawakan masih berkaitan dengan karakteristik genre sholawatz dzikir maupun qasidah. Namun secara musikal, musik yang dimainkan tidak lagi berkaitan dengan gambus dalam arti alat musik, maupun gambus sebagai format pertunjukan musik.

\section{KESIMPULAN}

Sebagaimana telah dipaparkaan, terminologi gambus yang mencakup banyak hal dalam spekturm musik di Indonesia. Satu istilah yang sama digunakan untuk menyebut berbagai fenomena dalam musik. Tampaknya yang terjadi dalam penggunaan istilah gambus di Indonesia adalah perluasan makna gambus itu sendiri. Berawal dari nama suatu alat musik, kemudian digunakan pula untuk menyebut sesuatu yang lain. Baik penyebutan nama alat musik, maupun perluasan 
pengertian yang muncul kemudian, digunakan secara bersamaan. Hal ini yang agaknya yang membuat istilah gambus menjadi tumpang tindih.

Penelusuran pengertian awal dan perluasan maknanya kemudian, akan membantu untuk melihat relevansi penggunaanya yang beragam itu. Sebagaimana yang telah dipaparkan dalam pembahasan, perluasan pengertian gambus dapat dibagi dalam 3 kategorisasi. Pertama, sebagai alat musik yang mengacu langsung pada alat musik khusus, seperti gambus Melayu, gambus zapin, gambus lunik, gambus Arab, gambus Albar, tingkilan, pating, dan lain-lainnya. Kedua, sebagai sususan instrumen musik yang dapat berupa permainan tunggal maupun dalam ensambel (orkes gambus). Ketiga, sebagai gaya musik (genre) yang dibawakan oleh gambus itu sendiri, baik secara tunggal maupun ensambel.

Secara kualitas maupun kuantitas, artikel pendek ini tentu tidak dapat mengakomodir seluruh kompleksitas fenomen musik gambus yang ada di Indonesia. Dan tentu saja masih banyak penggunaan istilah lokal serta genre musik yang belum disinggung ataupun didiskusikan dalam artikel ini. Namun demikian, penulis berpendapat, ketegorisasi sederhana semacam ini dapat menjadi penduan awal untuk masuk lebih dalam membelah kerimbunan fenomena musik gambus di Indonesia.

\section{DAFTAR PUSTAKA}

As'ad, Muhammad. 2018. 'Sabyan: Islamic Music and Popular Culture' dalam The Jakarta Post, akses https://www.researchgate.net/publication/326548282

Bart Barendregt and Wim van Zanten. 2002. 'Popular Music in Indonesia since 1998, in Particular Fusion, Indie and Islamic Music on Video Compact Discs and the Internet' dalam Yearbook for Traditional Music, Vol. 34 (2002), pp. 67113.

Berg, Birgit. 2007. Presence and Power of the Arab Idiom . 'Authentic Islamic Sound? Orkes Gambus Music, the Arab Idiom in Indonesian Islamic Musical Art'. Paper presented in Conference on Music of the World of Islam. Assilah 8-13 August 2007.

Berg, Birgit. 2011. 'Authentic Islamic Sound? Orkes Gambus Music, the Arab Idiom, and Sonic Symbol in Indonesian Islamic Musical Art' dalam Divine Inspirations: Music and Islam in Indonesia (Ed. David.D. Harnish \& Anne. K. Rasmussen). Oxford University Press, pp.207-240.

Capwell, Charles. 2011. 'From Dust to Platinum: Global Currents Through the Malay World of Musical Islam' dalam Divine Inspirations: Music and Islam in Indonesia (Ed. David.D. Harnish \& Anne. K. Rasmussen). Oxford University Press, pp. 197-206 
Harahap, Irwansyah. 2005. "Alat Musik Dawai”. Jakarta: Lembaga Pendidikan Seni Nusantara, buku uji coba PSN.

Hastanto, Sri. 2005. Musik Tradisi Nusantara. Musik-musik yang Belum Banyak Dikenal. Jakarta: Deputi Bidang Seni dan Film Kementrian Kebudayaan dan Pariwisata.

Hilarian, Larry Francis. 2005. 'The Structure and Development of the Gambus (Malay-Lutes)' dalam The Galpin Society Journal, Vol. 58 (May, 2005), pp. 6682.

Hilarian, Larry Francis. (2003). "The gambus (lutes) of the Malay world" dalam $A$ search in Asia for a new theory of music: A symposium organised by the Philippines,

Center for Ethnomusicology as the 7th International Conference of the Asia Pacific Society for Ethnomusicology (APSE). pp. 455-480.

Irawan, Ricky.2008. "Gambus Lampung Pesisir dan Sistem Musiknya : Kajian Musikologis Fenomena Maqam dalam Musik Gambus Masyarakat Lampung Pesisir". Skripsi S-1 Institut Seni Indonesia Yogyakarta.

Kartomi, J. Margareth.1980. Musical Strata in Sumatra, Jawa, and Bali, Music Many Culture (Ed. May Elizabeth). University of California Press, Ltd. Hal. 113.

Kunst, Jaap. 1973. Music in Java: It's History, It's Theory, and It's Technique. The Hague, Martinus Nijhoff.

Pulukandang, Mimy Astuty. 2009. 'Perubahan Musik Tradisi Gorontalo: Gambus dan Palopalo menjadi Tipotumba' dalam Jurnal Seni Dewa Ruci, Volume 6, Nomor 1, Desmber, h.79-98

Rasmussen, Anne.K. 2010. Women, the Recited Qur'an, and Islamic Music in Indonesia. University of California Press.

Sachs, Curt. 1940. The History of Musical Instruments. New York: Norton Compan. Inc. Publisher.

Sholikhah, Imoratus. 2008. Gambus sebagai Subkultur Relgius: Studi Kasus Praksis Gambus kelompok "Al-Asyik" Ambulu, jember, Jawa Timur. Tesis Pasca Sarjana pada Program Magister IImu Religi dan Budaya, Universitas Sanata Dharma, Yogyakarta.

Sutton, R.Anderson. 2011. 'Music, Islam, and the commercial media in contemporary Indonesia' dalam Islam and Popular Culture in Indonesia and Malaysia (Ed. Andrew Weintraub). Routledge Taylor \& Francis Group London and New York, pp.85-100.

Weintraub Andrew. 2010. Music and Malayness: Orkes Melayu in Indonesia. 19501965. In: Archipel, volume 79, 2010. Musiques d'un Archipel. Sous la direction de Dana Rappoport, de Jérôme Samuel. pp. 57-78; doi : 10.3406/arch.2010.4160 http://www.persee.fr/doc/arch 004486132010 num 7914160

Yampolksi, Philip. 1996. Melayu Music of Sumatra and Riau Island (Music of Indonesia). Washinghton DC, Smithsonian Institute.

Internet

- https://www.atlasofpluckedinstruments.com/africa.htm

- http://www.klangkosmos-nrw.de/detailsprofil 52238.html 
- http://inthegapbetween.free.fr/pierre/GAMBUS PROJECT/02 gambus swahil i coast and comoros.pdf

- http://inthegapbetween.free.fr/pierre/GAMBUS PROJECT/05d2 PORTFOLIO part5d2.pdf

- http://inthegapbetween.free.fr/pierre/GAMBUS PROJECT/01 PORTFOLIO.p df

- https://al-bab.com/albab-orig/albab/bys/articles/mokrani11.htm 